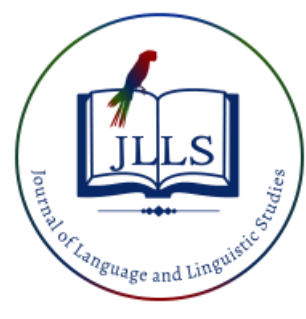

Available online at www.jlls.org

JOURNAL OF LANGUAGE

AND LINGUISTIC STUDIES

ISSN: 1305-578X

Journal of Language and Linguistic Studies, 17(3), 1341-1354; 2021

\title{
Potential of social networks' use in the protest movements
}

\author{
Olha V. Harmatiy a 1 iD, Mykhailo M. Basarab ${ }^{\text {b }}$ iD, Bekzhigit K. Serdali c iD, \\ Altyn B. Akynbekova d iD, Aliya T. Beldibekova e iD \\ ${ }^{a}$ Lviv Polytechnic National University, Lviv, Ukraine \\ ${ }^{b}$ Transcarpathian Institute of Postgraduate Pedagogical Education, Uzhhorod, Ukraine \\ ${ }^{c, e}$ Khoja Akhmet Yassawi International Kazakh-Turkish University, Turkistan, Republic of Kazakhstan \\ APA Citation: \\ ${ }^{d}$ Al-Farabi Kazakh National University, Almaty, Republic of Kazakhstan
}

Harmatiy, O. V., Basarab, M. M., Serdali, B. K., Akynbekova, A. B. \& Beldibekova, A. T. (2021). Potential of social networks' use in the protest movements. Journal of Language and Linguistic Studies, 17(3), 1341-1354. Doi: 10.52462/jlls.96

Submission Date:22/05/2021

Acceptance Date:20/08/2021

\begin{abstract}
This article studies the problem of social networks use as a platform for political mobilization of society's protest potential. Social networks are tools for spreading information. The aim of the article is to study the role of exposure and perspectives of social networks' usage in the formation and implementation of the protest potential in the society. Disclosed technological aspects, forms and methods of social networks' use as a means of formation and implementation of public protest potential. This article addressed practical experience of public's political mobilization in Ukraine and the Middle East. Actualized the tendency to use social networks as a medium of dissent formation and processes control instrument of political mobilization of the society. It was shown the basic directions of social networks' usage to achieve policy objectives (the promotion of political projects, work with target audiences) through the activation of dissent. It was determined that the use of social networks for political mobilization of society allows you to do it quickly enough, given existing precedents in other countries, factors and opportunities, ways to influence audience's opinion in the organization and carrying out protest campaigns, aligned at the main protest target audience of social networks - the young and the middle class.
\end{abstract}

Keywords: Internet; political mobilization; social interaction; protest campaigns; new media

\section{Introduction}

In modern society, social interaction is increasingly driven by possibilities of technical means and acquires properties pre-defined by these technologies. Under these conditions, the Internet as a collection of information and communication technologies and equipment, as a global means of mass media, constructs a fundamentally new information space of social interaction, being not only a tool for providing information to users, but also a powerful source of influence on them (Brunner, 2017). In this context it is relevant to study the impact of Internet technologies on the political sphere of public life, issues of masses control with the help of the information spread in network, search for balance between freedom of expression and threats of proliferation of protest and extremist influences. Since the rapid spread of information technologies, the number of Internet users has increased significantly -

\footnotetext{
${ }^{1}$ Corresponding author.

E-mail address: harmatiy5550@murdoch.in
} 
from a few million to a few billion. The key trend of the Internet development as a means of political communication is to develop and increase the role of the "new media", namely, social networks, with characteristic low-level state-control, significant mobilization potential, which contributes to high social self-organization of citizens. In this context, social networks' opportunities have an impact on socio-political processes, which leads to the emergence and development of new mechanisms of mass mobilization. Social networks have become an integral part of communication and the tool of civil society formation around the world, centre of views and current information exchange (Moraes et al., 2018; Valentine, 2018; Pylypenko, 2019).

Social networks become not only a means of entertainment, communication and information search, but also a political tool, being increasingly used not only as an information platform, but also as a coordinator, a mobilizer of various mass actions including protest movements. In this context, the issue of using the Internet and social networks for political mobilization of society, to justify factors and opportunities offered by the Internet in terms of managing the politicization of communication environment among the social networks' audience, the characteristics of social media's use in organizing and conducting protest campaigns, is of particular interest to the research community. Moreover, according to some authors (Jost et al., 2018; Kravtsov et al., 2019), it is a priority object of study in the communication space of social media. At the same time, this phenomenon has only recently become the object of scientific study that was predetermined by a relatively recent entry of the Internet and social networks in the socio-political practice, as well as the rapid development of political communication in the network in recent years (Atabekova, 2019; Atabekova, 2020).

The assertion that social networks are the "authoritarian regimes killer", that is - the democratization mechanism of the political system from below became widespread in modern socialpolitical discourse. A number of empirical examples, such as the Iranian Twitter Revolution, Egyptian Facebook Protests, Ukrainian Revolution of Dignity have not yet formed the basis for the systematization of sociological methodology, theory and methods of empirical research of social networks as a tool for the protest potential formation and implementation in society and mass mobilization to political protest actions, which are characterized by significant state influence on social networks, that restrict the use of social networking by civil society, the security of protests' organizers including peaceful and lawful (Owen, 2018). Thus, in the space of social networks audience management technologies do exist and social networks seem to be completely transparent, objective and ideology free only at first glance. From sociology's point of view characteristics that allow to detect mechanisms of actual interactions of individuals and groups within social networks are important (Volkova, 2015; Banerjee 2020; Saifnazarov et al., 2020).

The aim of this study is to investigate the role and prospects of social networks' use in the formation and implementation of the protest potential in the society. To achieve this, we need to solve the following research objectives:

1. Social networks' essence study as a means of political communication, role of the formation and implementation of the protest potential as one of the most important branches of political work in social networks;

2. Ascertainment of the peculiarities of mobilization mechanism of social networks functioning in the context of protest forms of political participation;

3. Study of technological aspects, forms and methods of social networks' use as a means of formation and implementation of public protest potential. 


\subsection{Literature Review}

Networks structures' research both in virtual and real space was actively conducted by sociologists at the end of XX beginning of XXI centuries. Network structure has become a central concept in the M. Castells's work (Castells, 2007). The concept of "network structure" and "network culture" are central in her scientific works. In the course of modern means of communication development Manuel Castells has identified "network" structures as attributes of a globalized society. He notes that "Networks are open structures that can indefinitely expand by including new nodes if those are able to communicate". With the help of networks which are used as a means of communication, the information - the primary resource of modern society - can be transmitted from one node to another (de Moraes et al., 2020).

In recent years, one of the dominant themes in the world science is studying new information and communication technologies. The researchers emphasize that in addition to the communication support functions, exchange of views and information, these technologies are becoming objects and means of information management, informational confrontation arena. The basic components of such researches are: modern communication systems, which provide different types of social communication, including social media; possible transformation of society's group structure in the Internet space; transformation of social and group actions under the influence of the communication processes. Problematics of interpersonal political communication on the Internet and social networks are being actively studied in the North American and European science primarily, where, in particular, the idea that the nature of political communication development on the Internet is a tool that contributes to the improvement of the political activity of citizens is common. This allowed it to take a specific niche in the political and communication process (Atabekova \& Gorbatenko, 2017).

A number of newest works of I. Mares and L. Young (2019), dedicated to electoral technologies on the Internet, the general theoretical aspects of their use in political struggle should be noted. The transformation of the Internet into a means of mass communication, to a great extent by means of social networks development, contributed to a sharp change in educational, age, professional, material and cultural level of the Internet audience. The public nature of social networks turns them into a kind of the society mirror (Barash \& Antonovskiy, 2019; Kyzdarbekova et al., 2014).

Studying works of contemporary researchers concerning the problems of network communications' usage in order to influence their members to solve political problems necessitates the transition from the study of common forms of work with the Internet for the implementation of political communications, to specific technological aspects of political and communication activities. Including the involvement of social networks, as a key and most dynamically developing communication platform in modern society for the realization of protest potential in specific countries (Pantoja, 2019). Today, social networks as a means of manipulation, control and mind control, when communications are realized by modifying the information about events or facts with the use of techniques such as fabrication of facts, propaganda, panic creation - take one of the most important places, largely shaping new forms of social dialogue. This being said, an understanding of the essential characteristics and the role of social networks as a global political player has not been established in the social knowledge yet. The expert community recognizes that on one hand social networks are an effective tool to conscribe to mass protests. On the other hand, social networks do not control their audience, giving it only a platform for communication, at any rate, on a global scale at present (Giraldo-Luque, 2018; De Aguilera \& Casero-Ripollés, 2020; Serdali et al., 2016). 


\section{Materials and Methods}

Protest activity of the population as a sphere of social reality serves as the object of this research. It is the direct carrier of the problematic situation, at which the cognitive activity is directed. Subjects of research are sides, properties, characteristics of protest activity, which are subject to direct study within the framework of given research. It was used comparative analysis while solving research problems in this article, thereby formulated conclusions about the possibility of intensifying protest potential, with a focus on the needs of youth and the middle class.

It was also used the selection by comparing available in the practice political mobilization system elements, the most important factors and trends in the development of protest potential. The article addressed practical experience of public's political mobilization in Ukraine and the Middle East. Actualized the tendency to use social networks as a medium of dissent formation and processes control instrument of political mobilization of the society. We have analyzed statistical and analytical surveys, that characterize the level and dynamics of protest activity. Usage of analytical and experimental method allowed to identify functional and cause-effect relations in the protest activity and to anticipate problematics development. Re-comparative method made it possible to identify general and specific in the course of time of comparative objects - protest actions in social networks, leading to the activation of the population's protest activity (Gura et al., 2020; Aizstrauta \& Ginters, 2015).

Scientific developments and publications of national and foreign scientists on the problems of society's protest potential and existing legislative and regulatory documents have found sufficient reflection in this research. Wherein, from sociology's point of view, issues and their solution methods associated with the mass information channels with the help of which mass communications are provided, are important. Sociologists, as well as specialists in information theory, are interested, above all, in the effectiveness problems. And if for the information theory the efficiency of communicative process is expressed in terms of speed, quality, accuracy, volume and the like, then sociologists are interested in the measure of impact of the communication process to the appropriate groups of people, which, in turn, also depends on the volume, speed, accuracy, etc. These results indicate how well and adequately the relevant information is perceived by a specific counterparty. Actual social indicators of the influence effectiveness will be the speed of transformation of influence objects' social behavior and its consistency with the objectives of said influence.

\section{Results}

In addition to the bilateral nature of communication, social networks offer the possibility to organize mass communication, which is carried out indirectly via the Internet and has a number of significant differences from the traditional media (which establish one-way communication: television, radio, printed media), which is expressed in a certain specifics of social networks as means of communication: social networks contain both the segment of high-quality informational content and a large segment of low and questionable quality; each user can produce content in social networks' environment today, while traditional media produce content determined by their owners and editorial policy; social networks demand user's knowledge and skills in computer (or other multimedia devices) and the Internet usage, while still not being generally accessible in some societies at the level of traditional media; social networks are significantly ahead of the television or the printed media in efficiency, because each of their users can publish information on the network, using even a portable handheld device, almost instantly; information placed in the social networks can be changed and most of the time authors are not responsible for its quality and reliability to the full extent (including legal). In this sense, social networks are less reliable, much less responsible in both ethical and legal sense, 
rather than traditional media. The dynamic development of social networks in modern society gives reason to believe that in this case we are dealing with a new kind of sociality manifestation (Fig. 1)

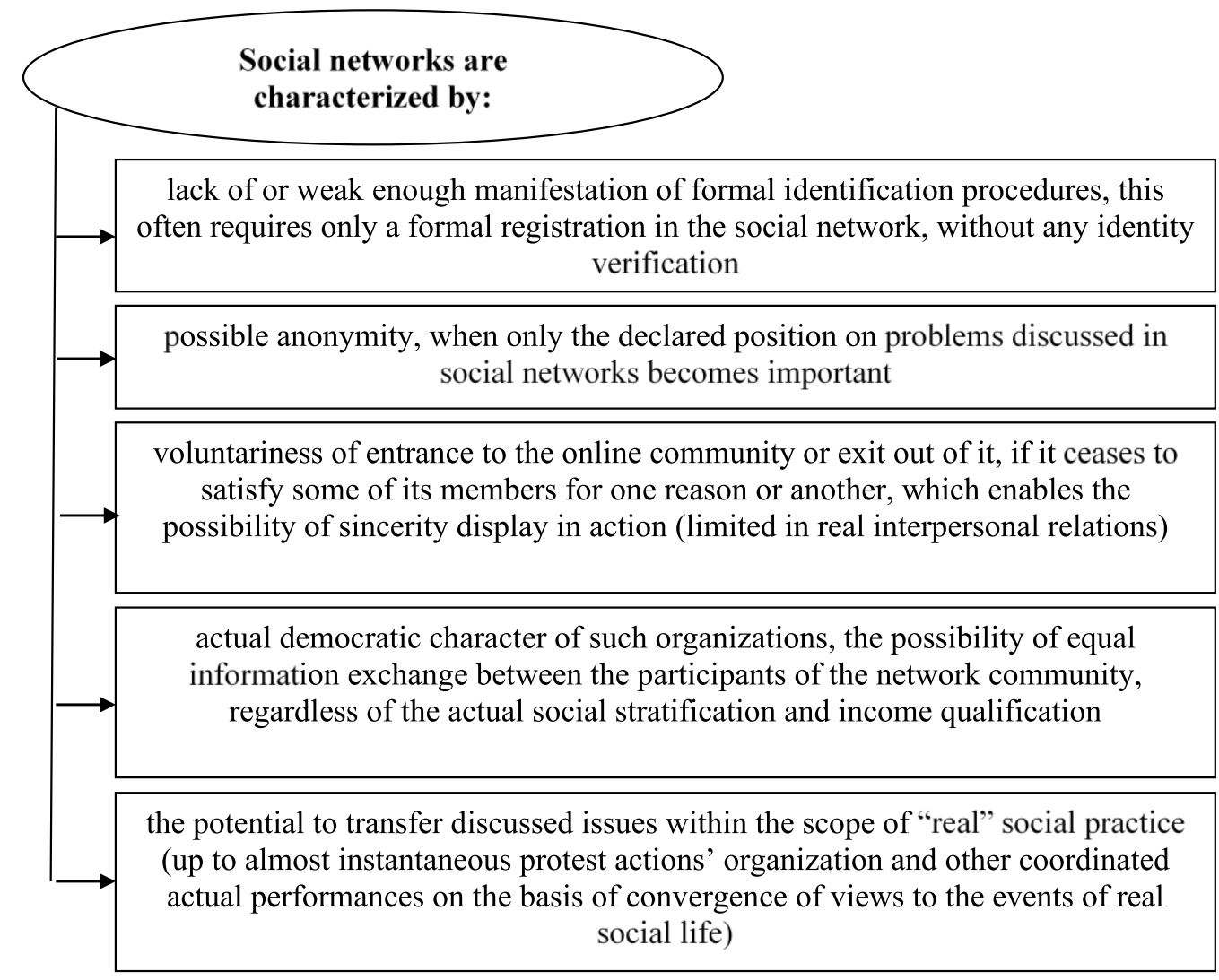

Figure 1. Forms of sociality display in social networks

One of the main mechanisms of the network communities' functioning is self-organization. Principles of individualism, freedom of expression, desire of equal and free access to all information have become the dominant socio-psychological basis for online communities. These instructions are not institutionalized, because there are no general "Rules of Internet Behavior" or "Network Constitution". You can draw an analogy with the real social space, where rules are also made basing on existing objective possibilities and limitations. Virtually every resource determines its own rules and laws of communication itself (Ginters et al., 2014).

If we generalize capabilities of the Internet as a means of socio-political communication, we can conclude that the Internet, and social networks in particular, have developed so much that they became one of the most powerful types of communication. They have also become means of influence on both thinking (consciousness), and actions of individuals and groups of people. At the same time in different countries and regions the approach to the relations regulation in the network may be different. In the United States, unlike Europe, there are voluntary behavior rules in the network, but the expansion of the information technologies of the Internet usage in everyday life makes the government look at this issue in a new way. As a result, US government free regulation of the Internet policy begins to succumb to serious criticism. In particular, unauthorized use of personal data, which became more frequent in recent years, beginning to cause alarm to different civil liberties and consumers rights protection organizations. Some observers have praised the stringent laws on the private information protection in some European countries (Serdali et al., 2018; Aizstrauta et al., 2013).

A characteristic phenomenon of recent years has been a noticeable shift in activity, especially young people and the middle class, registered in the US - Facebook, Twitter, etc. Activity on 
Facebook has become particularly intensive. It has also become characteristic for a number of Eastern and Central European countries that have chosen the democratic vector of development - Poland, Hungary, Bulgaria, Romania, Slovakia, Lithuania, Latvia, Moldova, Georgia, Ukraine. One of the world's leading companies Global Web Index, specializing in research on the Internet trends, indicated such global trends, on average, adults have accounts at 5.54 networks and actively use 2.82 of them.

For the information field such paradigm is also relevant, since the young are currently the most active users of the Internet, way ahead of older people who do not see urgent need in this. By connecting to the global network later the designated group would accept existing patterns of behavior, reinforcing current trends at the same time. In this context, for young people, many of whom are first time users of social networks, the usual for adult population paradigm is changing dramatically. Instead of a structured flow, which has news related character, young people are increasingly choosing channels that allow a simplified show of their emotional involvement in the life of society. Social networks play a significant role in the politicization of modern society and are, as practice shows, the most important tool for mobilizing citizens' protest activity around the world. Generated content here leads either to passive, or active forms of politicization. At the same time, user of social networks may just consume information product, enjoying different kinds of political manifestos, "memes", demotivators etc. And he may also participate in their development and move to the agreement of political actions with like-minded people, stipulating politicizing function of social networks in modern society (Suleimenov et al., 2019).

On the basis of summarizing two types of existing researches, we can distinguish two types of protest actions through social networks: virtual and real. Virtual actions include signing online petitions, sending messages to forum, or even hacker attacks. In this case, social network serves as a platform to bring participants together and as a resource sharing (both informational and financial) tool. It allows you to take many actions with or without partial acceptance of responsibility for their consequences. The potential anonymity of communication in social networks, dissolving oneself in the electronic space where the individual is "a set of recorded data and messages" makes an imprint on the real world, stipulating that not every active virtual world protester is capable of actual protest actions in real world. The same anonymity is a means to influence opinions and actions of people. Here an important role is played by the psychological aspect of why people react to a stranger in a social network differently than when they meet him on the street? This issue also affects political component of society's life.

As convincingly evidenced by the practice of modern mass protests' organization, social networks have become one of the most effective ways of involving a large number of active participants, especially young people. Common positions and general ideas are formed in networks, especially during the discussions that take place there. From time to time, social networks' participants (or rather, their most active, passionate groups) mobilize for common campaigns carrying under common slogans. As a result, today we are witnessing a growing inclusion of the Internet technologies in protest campaigns: carrying out protest actions in social networks; implementation of communication, coordination of actual protest actions between subjects of protest activity in social networks; coverage of protest activity in social networks, so that protest campaigns, in fact, largely get covered both in traditional media and get additional informational support and basis for the mobilization of population.

The use of social networks for protest mobilization allows you to quickly find like-minded people, to establish horizontal links. But the scheme, on which communication is based, depends on who builds it. Considering massive political protests and the role of new media in their organization, it should be noted that social networks have become a means for the dissemination and exchange of information between its members and those who helps to organize masses offline. With the development of social networks, in the last decade the world has seen examples of social media use by 
citizens protesting against the political regimes in their own countries: with the help of social networks, participants of rallies and protest campaigns use new tools for information sharing and fundraising. In addition, they made invitations, calls and agitation, organize online broadcasts. Through social networks protest actions are coordinated around the world (Suleimenov et al., 2021).

Thus, social networks have become not only the environment for discussion and shaping of protest mood, but also a tool for effective management of masses in the course of political actions. So, largely using social networking tool as mobilizing to protest activity (along with more fundamental reasons that stipulate the possibility of protest activity and its forms), there have been developed a series of "color" revolutions in the former Soviet Union: in Moldova, Kyrgyzstan, Georgia, and Ukraine. Mobilization capabilities of Facebook and Twitter have fully manifested in the Middle East in the past decade. That way, those were social networks that played a crucial role in the "Arab Spring", uniting disparate opposition groups and allowing them to circumvent the censorship which the traditional media in this region were prone to. During the Orange Revolution (2004) and the Revolution of Dignity (2013-2014) in Ukraine, social networks played a prominent role. They totally supported the pro-European stance, which allowed the opposition to the then government to cover events more quickly than the printed media, to plan a protest by exchanging messages.

An important issue requiring scientific consideration and decision is that, on one hand, the strengthening of political self-organization and civil society power control by means of active communication in social networks, leads to the formation of a well-organized, established democratic society. But on the other hand, it may create barriers that hinder the functioning of power structures, in accordance to the formula "a strong society - a weak state". According to researcher J. Migdal in new democratic states the main conflict takes place on the effectiveness of the authorities in the face of increasing civil society control. It is because the goals of politicians and the general public may not be the same. In young democracies, mass political protest mobilization can significantly reduce the stability and efficiency of the political and administrative institutions with its pressure (Migdal, 1987). The growth of citizens' activity and their commitment to find a real subjectivity, the possibility to influence the adoption of political and administrative decisions is becoming a challenge for the whole political system, especially in case of protest forms of political participation (Klepar, 2019).

Thus, there is a question in application of the legitimate means of influence on political decisionmaking and functioning of the political system as a whole. If there are such means - then the political involvement takes conventional forms. And if they are absent, the only way to relieve social tension are protest actions which, at the same time, have a high destabilizing potential. So, if democracy is not fully functional, and the participation of citizens is reduced only to the elections' participation, which to a certain extent can be said of conditions (where participation in the elections also doubtfully reflects the real public opinion due to the frequent cases of fraud), void, that is filled with potential non-formalized and non-conventional forms of protest political participation, arises in the structure of political opportunities.

The question arises, whether the existing structure of political opportunities is capable to remove and neutralize further conflicting tensions between the interests of different communities and elites including regional. There is no institutional, legal mechanism to deal with this contradiction. So, at this point the main instrument of the state is the information space control and the restriction of rights of country's citizens to express their political views. In absence of further potential in tightening such mechanisms, it is possible to generate conflict along the lines of the inter-regional, socio-cultural, class, ethnic differences and divisions. The political orientation can be imagined from such positions: as ideological orientations: awareness of political processes, phenomena and events as well as political identification, political beliefs; as orientation with respect to public administration institutions: assessment of authorities and persons exercising political functions; as the orientation with respect to 
their own activities: political involvement and political behavior. One of the reasons for such a state of affairs can be: distrust of government institutions; people's ideas about the failure or inability of an individual to influence the course of political events (Vinarchuk et al., 2021).

Speaking of technologies, which can encourage citizens to invoke protest activity on social networks, it should be noted that the union of the virtual network community members occurs in specific ways. Peculiar virtual user groups are often built based on common political beliefs, influence on the members of which is often accompanied by the effect of viral marketing, when the "infected" by the protest idea active group participants are beginning to develop and disseminate it themselves. It is important for this process to be controllable. That is, for the implementation of policy objectives in social networks it is necessary, first of all, to clearly define tasks, which may be: attracting new followers to support a political force or a leader that are able to organize the protest; inversion of the Internet community to the shape of political force, actually capable of organizing and realizing protest campaigns; expansion of protest ideas through opinion leaders, presented in a social network.

A significant part of political movements and parties studies the reaction of a certain population category on actions and statements of politicians, on political consultants' ideas. They also carry out agitation in social networks. On the other hand, they borrow ideas and expressions. After defining the objectives and expected results, it is necessary to clearly define the target audience. In terms of the policy objectives implementation, it can be both broad (general political discussion platforms) and narrow (ideological platforms). While in the second case, the result may be easier to attain, the first one has the advantage of coverage range and development capacity, which is important for the organization of a truly mass and effective protest movement (Kostiuk, 2020).

The very nature of thematic groups in social networks that bring together potential like-minded, leads to the need to establish a specific communication space within which ideas, over which protests may occur and materialize, are generated. A striking example - the unification in Facebook in Ukraine, November 2013, behind the idea of protest against the refusal of the President of Ukraine Viktor Yanukovych to sign the agreement on the EU-Ukraine Association (Association agreement..., 2017). In this regard, key aspects of political work with social networks are clear goals, ideas, right tactics, opinion leader's readiness to lead the communication process to achieve desired results. Social network as a specific association of people also is subject to a certain general principle: assertion, repetition and infection. There is no need to set the goal of achieving maximum frequency of posts, the main thing is to keep a steady pace and develop the key idea. To do this 4-5 messages per day are needed, but formulated in accordance with the key political protest idea.

When the work with social networks starts, we have to consider that it may take a long time and require significant resources, because it requires opinion leaders' inclusion, promoting protest ideas to the general discussion process. It requires them to conquer space and authority among other participants, which can create some controversies regarding agreement deadline of the protest campaign. After first steps of the opinion leader in social network are made, it is necessary to switch to the direct fulfilment of political agenda. To do this, it is necessary to learn a few techniques of discussions' management in social networks. In particular, to ensure that the discussion is monitored and controlled, it must appear unbiased and uncontrollable. Only in this case network community's representatives are willing to believe in proposed ideas. In general, information that is designed to encourage protest actions may be both completely objective and distorted. A number of techniques are traditionally used in case of informational manipulations: fabrication, misrepresentation, interpretation, concealment, headlines and sources of information manipulation, inaccurate citations. Obviously that while working with social networks audience's readiness and its access to alternative sources of information (which is not difficult in modern society) should be taken into account. That is why facts interpretation acts as the main direction of work. 
The discussion should not stop, protest idea, which is not filled with a new content becomes uninteresting and gets relegated to the background, which means the inevitable failure of the communication strategy. Therefore, it is necessary to ensure regular activity with the social network, regardless of the number and size of messages. Communication strategy should be formed for a successful response to the criticism. It should include a common theme of the discussion, the sequence of material presentation, possible variants of counterreaction, answers to negative and positive reviews. Informational messages of different tonality and intensity should be prepared. According to disputants, debate expansion should take into account credibility and information objectivity. Accordingly, argument intensity and thoughts formulation should unfold in the evolutionary plane, starting from the most neutral both in source and content, and then going to a fully consistent and categorical.

Characterizing generalized model of political mobilization to protest activity of society through social networks, we should highlight its basic structural blocks and determine the sequence of their interinfluence (Figure 2). The essence of this model is to use social networks to organize social communities of real people, collectives, groups, movements and organizations to create preconditions for formation and implementation of the necessary protest action.

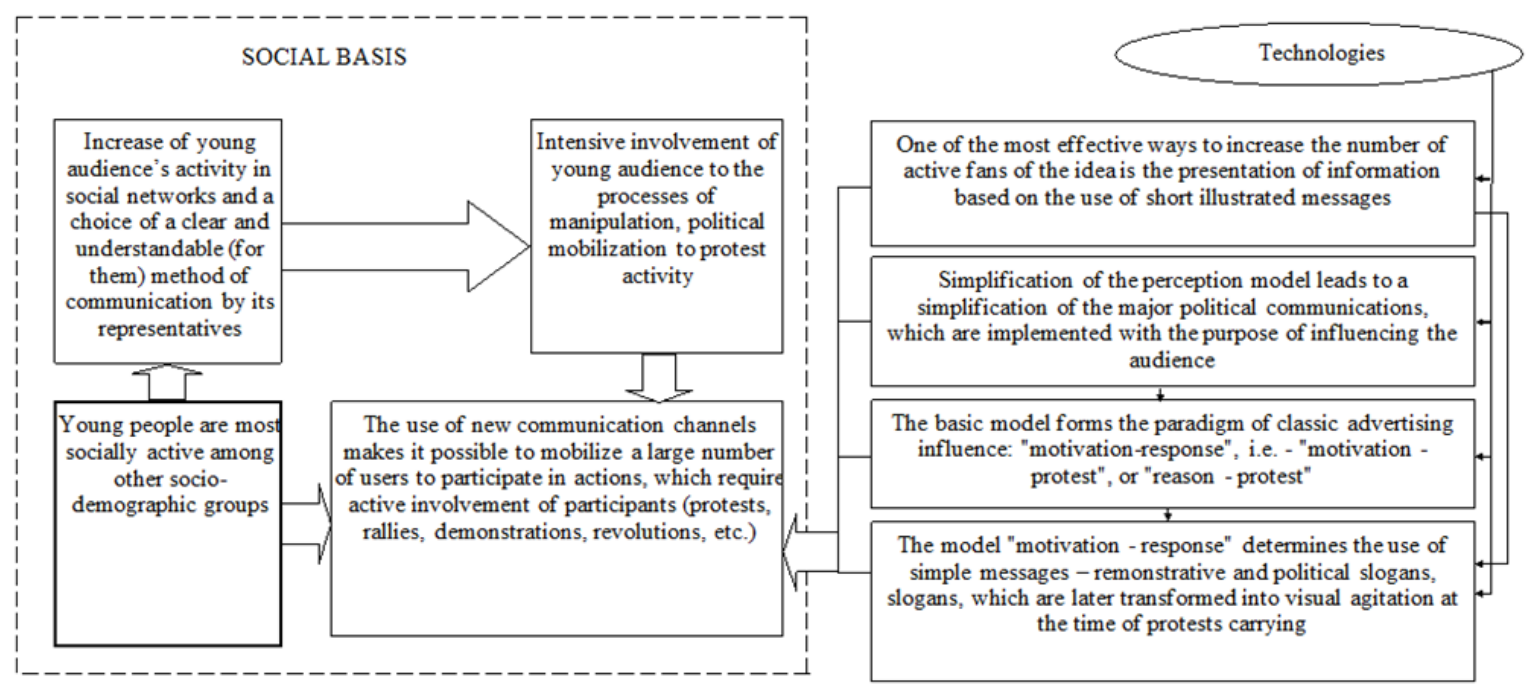

Figure 2. Model of political mobilization to protest activity through social networks

Thus, informational and communicational technologies, especially social networks, have changed the landscape of collective action significantly. Both oppositionists-democrats, opponents of authoritarianism and corruption, radical anti-democratic forces or terrorist groups can use social networks as a mechanism of political mobilization of protest. Therefore, we should be aware of the problematic aspect of this mechanism, that social networks:

1. Transfer communication to the virtual sphere, which inevitably leads to a shortage or lack of personal contact between members of the mobilized group and, altogether, political participation exclusively on-line, which significantly depletes the arsenal of political activities and their effectiveness.

2. Do not create an alternate dimension of reality, but rather recreate reality in the virtual dimension; thus, mass protest mobilization which occurs through social networks, recreates social separation, in particular, structure of inequalities and social barriers existing in the real world. 
3. Cause a situation in which a user acts biased on the network, in accordance with their political views, values, recreating all particular separations that exist in reality.

4. Often characterized by a lack of a unified ideology, principles or programs of action that leads to the internal discussions, instability of formed protest groups, the lack of a common ethics of political participation.

5. Allow to avoid legal monitoring, to distribute illegal propaganda, to instigate hostility, glorify heroes and martyrs of protest political movements, plan terrorist acts, gather strategic and tactical information, recruit new members and collect funds.

The leading role in harnessing the potential of social networks in society, in addition to the established practice of implementation of the state's interests in the social support of its actions, should belong to the democratic elements of influence and civil society's effort. Subjects of civic identity formation in social networks are political leaders, government officials, civil society activists and journalists. It does not significantly differentiate virtual information space from traditional, except for the fact that social media communication participants are considered equal, and every man can make a choice concerning one or another informational product that appears in news feed. This means that a person becomes a co-author of civic identity, rather than a passive consumer of what is imposed by state, parties and community leaders. The difference of virtual communication space from traditional is also the personification of political and social actors, which significantly reduces distance in relationship between abstract and distant authoritative institutions and citizens. It increases communications' transparency, creating favorable conditions for overcoming alienation from power and self-awareness of oneself as an equal participant of the governance process.

\section{Discussion}

Various researchers have fundamentally different assessments of the role of social networks in the organization of socio-political actions. Some scholars (Banerjee, 2020; de Moraes et al. 2020), and we can agree with this, express confidence that their role in the organization of collective action in the era of information society is very significant and will continue to grow. At the same time there are skeptics who say that such funds should be seen more as a tool for shaping public opinion, rather than an effective platform for coordination. At the same time, we believe that social networks make it possible, to some extent, to assess the extent of protest events, not only to understand what information, occasion, event or trigger is responsible for protests' activation, but also to see how many people adhere to this (protest) point of view.

Among the variety of spheres which concern social media, socio-political is a significant one. While working on the article, we have found evidence in favor of the fact that the activity in social media is associated with a form of political participation. Possible use of social media's mobilization potential in an extremist way is of particular concern. The experience of society indicates a rejection of formal institutional forms of mass mobilization and political participation by great masses of population: political parties and civil society organizations are still not effective collective action structures. It is indicated by the relatively low membership data in such structures and popularity of these structures in the network. Taking this into account, social networks represent a mobilization tool agreeable to the modern society to the greatest extent. It is combining elements that compensate for lack of feel for citizens' political subjectivity, flexibility and spontaneity, horizontality and voluntariness (Giraldo-Luque, 2018).

Effective social technology can be seen in action through the use of social networking opportunities in the organization of protest activity. It combines collective optimization of protests and transmission of protesters' mechanisms and action experience using social networks both within and between states. 
This technology is new and dangerous for the existing political regimes. The phenomenon of network revolutions is still understudied, often the scientific community simply does not have time to analyze the empirical data around social networks and reflect in response to changes in social networks' activity and function. That is why this problematic requires further research on interrelationships, mutual political protest and new forms media coverage. Factor of social networks in protest movements' organization should be studied, as well as for guaranteeing public and state security.

In the further research it is expedient to consider the regularities of interrelation disclosure problematic of political participation forms online and offline. Questions of substantiation of protest potential measuring tools, which would discuss not only respondents' intent but also about their political participation experience, including the protest one, also remain open. We have also to bear in mind that most active users of social networks at the moment are young people, the bulk of new users will be represented by older people (often with protest activity experience). For which reason the described model will be applicable not only to youth, but also to people who are less prone to impulsive decisions and active doings. As a result, after the change of environment the model of protest political mobilization of the population itself will undergo modification. That requires a detailed, in-depth and timely scientific understanding.

\section{Conclusions}

Social networks as one of the most effective means of communication and organization in all fields of expertise are being actively used. They will be used in politics, removing spatial and temporal barriers to information exchange ways and creating new forms of ordinary citizens' unifications including unions over the protest activity. Thus, social network becomes a communicatory platform on which citizens express their opinions and emotions without fearing sanctions by the political authorities. On one hand, it may slightly reduce the emotional fuse, and distance from the expression of radical protest forms, on the other - it remains a powerful tool of masses mobilization to organize actual protests. In this article, the formation and realization of protest potential is considered as one of the important directions of political work in social networks. It has its own specific features associated both with peculiarities of people socialization through social networks and networks activity in the context of a certain countries. Revealed technological aspects, forms and methods of social networks use as a means of formation and implementation of public protest potential.

In general, work with social networks may have the following policy outcomes that are important for the organization of protest actions: change or transformation of political beliefs of a target group; creation of a new protest-minded network union with a potential exit to a real political environment; necessary information distribution among target group's representatives; information environment's research on the degree of its readiness for the manifestation of protest activity; check of protest political ideas as to their compliance with the public's expectations and willingness to support them. To achieve these results, work with social networks requires precise planning of events, expected objectives and areas of work, integration in the online community with the gradual expansion of political messages publication, which must meet traditions' requirements of a given network community.

The problem of public opinion manipulation of citizens in social networks, of course, has not only the technological side, but is also a reflection of the economic, social, political and other levels of reality. Events specific to countries in recent years show that the basis of protests, which had the most social resonance, were young people. The same, who shape new trends in information development and perception. This suggests that the model "stimulus-response" addressing interests of young people 
in the first place, will have substantial opportunities for practical application, finding support in social networks and new popular activity groups.

\section{References}

Aizstrauta, D., \& Ginters, E. (2015). Integrated acceptance and sustainability assessment model transformations into executable system dynamics model. Procedia Computer Science, 77, 92-97.

Aizstrauta, D., Celmina, A., Ginters, E., \& Mazza, R. (2013). Validation of integrated acceptance and sustainability assessment methodology. Procedia Computer Science, 26, 33-40.

Association agreement between the European Union and its Member States, of the one part, and Ukraine, of the other part. (2017). Retrieved from: https://trade.ec.europa.eu/doclib/docs/2016/november/tradoc_155103.pdf.

Atabekova, A. (2019). Technology-facilitated harm to individuals and society: Cases of minor's selfproduced sexual content in Russia. Journal of Critical Reviews, 6(6), 410-415.

Atabekova, A. (2020). University discourse to foster youth's sustainability in society amidst COVID19: International and Russian Features. Sustainability (Switzerland), 12(18), 2463.

Atabekova, A., \& Gorbatenko, R. (2017). Multilingual community and translation: Focus on information processing to enhance quality. Information (Japan), 20(7), 4677-4692.

Banerjee, T. (2020). The collective interests of large corporations: Social movement protest and the policy-planning network. Sociological Quarterly, 61(3), 389-421.

Barash, R.E., Antonovskiy, A.Y. (2019). New social movements and their evolution in the network age. Voprosy Filosofii, 2019(7), 99-110.

Brunner, E. (2017). Wild public networks and affective movements in China: Environmental activism, social media, and protest in Maoming. Journal of Communication, 67(5), 665-677.

Castells, M. (2007). Communication, power and counter-power in the network society. International Journal of Communication, 1(1), 238-266

De Aguilera, M., Casero-Ripollés, A. (2020). Technologies for transformation? Social media before political and social change. An introduction. Icono14, 16(1), 1-21.

de Moraes, G.H.S.M., Pelegrini, G.C., Pinheiro, G.T. (2020). Social media and protests engagement: What's gender got to do with it? Journal of Content, Community and Communication, 11(6), 22-31.

Ginters, E., Aizstrauts, A., \& Chinea, R.M.A. (2014). Sociotechnical aspects of policy simulation. In: Handbook of Research on Advanced ICT Integration for Governance and Policy Modeling (pp. 113-128). Hershey: IGI Global.

Giraldo-Luque, S. (2018). Social protest and stages of moral development: An analytical proposal for the study of social mobilization in the 21st century. Palabra Clave, 21(2), 469-498.

Gura, D., Khoroshko, A., Sakulyeva, T., \& Krivolapov, S. (2020). Intelligent data processing for navigating drones. Journal of Advanced Research in Dynamical and Control Systems, 12(2 Special Issue), 396-401.

Jost, J.T., Barberá, P., Bonneau, R., Langer, M., Metzger, M., Nagler, J., Sterling, J. \& Tucker, J.A. (2018). How social media facilitates political protest: information, motivation, and social networks. Political Psychology, 39, 85-118. 
Klepar, M.V. (2019). Stages and tendencies of formation of a network of institutions of higher education of Ukraine for the training of future international experts. Bulletin of Mukachevo State University. Series "Pedagogy and Psychology", 1(9), 73-77.

Kostiuk, S.S. (2020). Development of intercultural communicative competence of future specialists in the field of information technologies in the process of foreign languages learning. Scientific Bulletin of Mukachevo State University. Series "Pedagogy and Psychology", 6(2), 103-112.

Kravtsov, Y.S., Chetnverikova, N.A., Saifnazarov, I.S., Dombrovska, O.V., \& Khovpun, O.S. (2019). Philosophical purpose of social communication in the aspects of sustainable development of modern social reality. Asia Life Sciences, 1, 329-337.

Kyzdarbekova, M.A., Serdali, B., Bakirova, Z.A., Nurtazayeva, N.M., Doszhan, S.M., Kasymbekova, K.A., Djamalova, S.A., \& Bimaganbetova, A.K. (2014). Nonverbal means of pedagogical dialogue in conditions of cross-culture communication. Life Science Journal, 11(Spec. Issue 6), 238-244.

Mares, I., Young, L.E. (2019). Conditionality \& Coercion: Electoral Clientelism in Eastern Europe. Oxford: Oxford University Press.

Migdal, J.S. (1987). Strong States, Weak States: Power and accommodation. In Understanding political development (pp. 391-434). Boston: Little, Brown \& Co.

Moraes, G.H.S.M., Cappellozza, A., Silva, D.S. (2018). Technology and the Dissemination of Information to participate in Protests through Social Networks. IEEE Latin America Transactions, 16(1), 287-293.

Owen, S. (2017). Monitoring social media and protest movements: Ensuring political order through surveillance and surveillance discourse. Social Identities, 23(6), 688-700.

Pantoja, S.M.R. (2019). The sense of the common and the political in virtual social networks. Aula Abierta, 48(2), 203-211.

Pylypenko, D. (2019). Editorial. Astra Salvensis, 1, 9-10.

Saifnazarov, I., Muhtarov, A., Sultonov, T., \& Tolibov, A. (2020). Religious tolerance, unity of knowledge and faith issues highlighting in Imam Bukhari Hadiths. International Journal of Advanced Science and Technology, 29(5), 1846-1853.

Serdali, B.K., Ashirbekova, G.S., Isaeva, Z., \& Adieva, P.M. (2016). Newspaper headings as a means of presenting priority and secondary information. International Journal of Environmental and Science Education, 11(11), 4729-4738.

Serdali, B.K., Beldibekova, A.T., Zhaxylykbaeva, R.S., Uzbekova, G., \& Tursyn, K. (2018). Democratic principles of education in media environment. Espacios, 39(30), 1-16.

Suleimenov, I., Bakirov, A., \& Moldakhan, I. (2021). Formalization of ternary logic for application to digital signal processing. Advances in Intelligent Systems and Computing, 1259, 26-35.

Suleimenov, I.E., Gabrielyan, O.A., Bakirov, A.S., \& Vitulyova, Y.S. (2019). Dialectical understanding of information in the context of the artificial intelligence problems. IOP Conference Series: Materials Science and Engineering, 630(1), 012007.

Törnberg, A., Törnberg, P. (2017). Modelling free social spaces and the diffusion of social mobilization. Social Movement Studies, 16(2), 182-202. 
Valentine, O. (2018). Top 10 Reasons for Using Social Media. Retrieved from: https://blog.globalwebindex.com/chart-of-the-day/social-media.

Vinarchuk, N.M., Haliuka, O.S., \& Sholovii, M.-T.I. (2021). Features of using health-saving and ICtechnologies in the formation of a socially mobile teacher in a pandemic condition. Scientific Bulletin of Mukachevo State University. Series "Pedagogy and Psychology”, 7(2), 70-78.

Volkova, S., Bachrach, Y. (2015). On predicting sociodemographic traits and emotions from communications in social networks and their implications to online self-disclosure. Cyberpsychology, Behaviour, and Social Networking, 18(12), 726-736.

\section{AUTHOR BIODATA}

Olha V. Harmatiy has done PhD in Journalism, Associate Professor, Department of Journalism and Mass Communication, Lviv Polytechnic National University, Lviv, Ukraine.

Mykhailo M. Basarab has done PhD in History, Associate Professor, Department of Social-Humanitarian and Ethical-Aesthetic Education, Transcarpathian Institute of Postgraduate Pedagogical Education, Uzhhorod, Ukraine.

Bekzhigit K. Serdali has done PhD in Philology, Professor, Department of Journalism, Khoja Akhmet Yassawi International Kazakh-Turkish University, Turkistan, Republic of Kazakhstan.

Altyn B. Akynbekova has done PhD, Lecturer, Department of Print and Electronic Media, Al-Farabi Kazakh National University, Almaty, Republic of Kazakhstan.

Aliya T. Beldibekova has done PhD in Philology, Lecturer, Department of Journalism, Khoja Akhmet Yassawi International Kazakh-Turkish University, Turkistan, Republic of Kazakhstan. 